\title{
IMPLEMENTASI TEKNOLOGI FERMENTASI SUSU KEFIR PADA PETERNAKAN SAPI PERAH DI KOTA PAYAKUMBUH
}

\author{
Ferawati $^{*}$., Erpomen, Yulianti Fitri Kurnia, Reswati, dan Khalil \\ Fakultas Peternakan Universitas Andalas \\ ${ }^{*)}$ Email: ferawati@ansci.unand.ac.id
}

\begin{abstract}
ABSTRAK
Program ini dilakukan di peternakan mandiri Abe Farm Sari Bulan yang berlokasi di kelurahan Sawah Padang, Kecamatan Payakumbuh Selatan dan Kelompok Tani Sapi Perah Tapian Agam di Koto Baru, Payobasuang Kecamatan Payakumbuh Timur. Kegiatan ini bertujuan untuk mengatasi permasalahan susu segar yang tidak terjual secara maksimal, penyimpanan susu yang relatif singkat serta dapat mengurangi nilai gizi serta menurunkan kualitas dan harga jual setelah penyimpanan. Masalah ini dapat diatasi dengan beberapa pendekatan yaitu metode pembelajaran berupa pelatihan dan pendampingan dengan tim pengabdi sebagai fasilitator dalam penyelesaiaan masalah. Dalam hal ini tim pengabdi mengaplikasikan pembuatan kefir sebagai salah satu solusi dari permasalahan yang di alami peternak sapi perah dikota Payakumbuh. Adapun tujuan dilaksanakannya kegiatan ini adalah meningkatkan pengetahuan peternak tentang keberagaman pengolahan susu, meningkatkan skill peternak dalam pembuatan kefir dan produk turunannya, menambah wawasan dan motivasi peternak dalam mengembangkan produk olahan susu yang langsung dipasarkan secara konvensional maupun secara online sehingga berdampak pada peningkatan penghasilan peternak. Hasil dari kegiatan ini adalah meningkatnya pendapatan peternak dari penjualan susu segar yang semula dijual dengan harga Rp 10.000.-/ liter namun setelah diolah mejadi kefir harganya mampu mencapai Rp 30.000.-/ liter.
\end{abstract}

Kata Kunci: kefir, susu, pengolahan, pelatihan, pemberdayaan

\section{Implementation of Kefir Milk Fermentation Technology on Dairy Cattle Farmers in Payakumbuh City}

\begin{abstract}
The program is conducted at Abe Farm Sari Bulan independent farm located in Sawah Padang, South Payakumbuh and Tapian Agam farm group in Koto Baru, Payobasuang, East Payakumbuh. The empowerment program aims to overcome the problem sales milk that are not optimal. Relatively short milk storage and can reduce nutrition and reduce the quality and selling price after storage. This problem can be overcome by several approaches, namely the learning method in the form of training and mentoring with the service team as a facilitator in solving problems. In this case, the empowerment program team implemented the making of kefir as a solution to the problems experienced by dairy farmers in Payakumbuh city. The purpose of this program are to increase farmers' knowledge about the diversity of milk processing, improve farmers' skills in making kefir and derivative products, increase the insight and motivation of farmers in developing dairy products that are directly marketed conventionally and online so that it has an impact on increasing farmers' income. The result of this program are to increase in farmers' income from the sale of fresh milk which was initially sold at Rp. 10,000/liter but after processing it into kefir the price reached Rp. 30,000/liter.
\end{abstract}

Keywords: kefir, milk, processing, training, empowerment 


\section{PENDAHULUAN}

Kelompok Tani Sapi Perah Tapian Agam di Koto Baru, Payobasuang Kecamatan Payakumbuh Timur dan Peternakan Sapi Mandiri Abe Farm Sari Bulan yang berlokasi di kelurahan Sawah Padang, Kecamatan Payakumbuh Selatan merupakan peternak mitra dalam pelaksanaan implementasi teknologi susu menjadi kefir. Pemilihan mitra didasari atas permasalahan yang hampir sama antara kedua peternak. Permasalahan utama yang sering dialami peternak sapi perah adalah pemasaran susu dan daya simpan susu yang relatif singkat. Susu saat masih segar dihargai Rp 10.000,-/ liter. Susu yang tidak terjual dan dibekukan apabila dijual kembali maka dengan harga yang relatif rendah yaitu Rp 8.000.-/liter biasanya dibeli oleh peternak kambing sebagai susu pengganti untuk anak kambing. Keuntungan yang diperoleh peternak juga relatif rendah bila dibandingkan dengan biaya produksi yang harus dikeluarkan. Disamping itu, rendahnya minat masyarakat terhadap susu segar menjadi penyebab tidak terjualnya susu dengan maksimal. Oleh karena itu diperlukan inovasi teknologi di dalam pengolahan susu menjadi produk dengan nilai jual lebih tinggi dan cita rasa yang disukai konsumen serta memiliki potensi pangan probiotik.

Payakumbuh merupakan kota dengan masyarakat yang sudah mulai menyadari akan pentingnya memperhatikan jenis makanan yang akan dikonsumsi. Banyaknya makanan dan minuman dengan penambahan pengawet dan penyedap rasa yang dapat mengakibatkan timbulnya penyakit tertentu. Sehingga masyarakat beralih mengkonsumsi makanan alami dan dengan gizi cukup dan memiliki nilai manfaat. Hal ini didukung oleh kesadaran masyarakat akan kesehatan. Mengingat banyaknya penyakit- penyakit mematikan seperti kanker yang sulit untuk dilakukan pengobatan. Makanan dengan kandungan bahan alami yang berdampak positif terhadap kesehatan menjadi pilihan konsumsi masyarakat saat ini.

Perkembangan teknologi pengolahan pangan di era global ini memberikan peluang peningkatan diversifikasi produk pangan yang dapat dijual dengan harga lebih tinggi serta dapat memperpanjang masa simpan susu. Salah satu teknologi pengolahan yang berkembang saat ini adalah produk susu fermentasi. Produk susu fermentasi memiliki nilai manfaat yang menyehatkan bagi tubuh terutama untuk pencernaan. Selain itu dengan adanya perombakan laktosa selama fermentasi maka susu juga dapat dinikmati bagi konsumen yang tidak mampu mencerna laktosa (Lactose Intolerance). Intoleransi terhadap laktosa adalah gangguan pencernaan yang biasanya dialami oleh mereka yang tidak mempunyai enzim laktase atau punya sedikit sekali di dalam saluran pencernaannya. Dengan meminum produk probiotik, laktosa di dalam produk ini sebagian sudah dicerna oleh bakteri asam laktat. Bakteri asam laktat dalam susu fermentasi menghasilkan enzim lactase didalam saluran pencernaan, mencerna laktosa hingga mengurangi lactose intolerance.

Produk fermentasi dapat menjadi pilihan masyarakat karena rasa nya yang khas serta kandungan gizi yang tidak mengalami pengurangan. Namun untuk membuat susu fermentasi, peternak belum tersentuh teknologi pegolahan susu. Selain pembuatan starter fermentasi yang seringkali tidak berhasil dan sulitnya mendapatkan starter menjadi kendala dalam pembuatan produk fermentasi. Fermentasi susu kefir menjadi pilihan dalam permasalahan ini. Pembuatan kefir dapat digunakan tanpa starter bakteri melainkan dengan granula kefir. Salah satu hal yang sangat mendukung adalah penggunaan granula kefir untuk pengolahan fermentasi susu menjadi kefir dapat 
digunakan secara berulang. Sehingga peternak tidak membutuhkan biaya produksi yang tinggi.

Kefir merupakan minuman berbahan susu yang difermentasi dengan bakteri dan yeast yang berasal dari granula kefir. Minuman kefir belum dijual secara komersial seperti halnya yoghurt. Kefir banyak dikembangkan dipulau jawa sedangkan di Sumatera Barat sangat sulit menemukan minuman ini. Sulitnya menemukan kefir di Sumatera Barat juga disebabkan oleh biji kefir yang tidak dijual secara komersial. Granula kefir hanya dijual oleh penggiat kefir dalam komunitas mereka. Kefir juga memiliki banyak manfaat bagi kesehatan yang belum banyak diketahui masyarakat. Umumnya penggiat kefir menjual kefirnya kepada masyarakat umum dan beberapa penderita penyakit tertentu. Bagi konsumen yang menderita penyakit tertentu perlu bimbingan oleh penggiat kefir dan ahli kesehatan untuk takaran konsumsi karena kefir bersifat dapat menyebabkan detoksifikasi.

Kadar asam laktat kefir berkisar antara 0,8-1,1\%, alkohol 0,5-2,5\%, sedikit $\mathrm{CO}_{2}$, kelompok vitamin B serta diasetil dan asetaldehid. Komponen dan komposisi kefir bervariasi tergantung granula kefir yang digunakan, temperatur, waktu fermentasi serta bahan tambahan lainnya. Kefir dengan kadar lemak tinggi dapat dihasilkan dengan menggunakan susu berkadar lemak tinggi sedangkan penggunaan susu skim akan menghasilkan kefir berkadar lemak rendah. Kadar laktosa bahan baku, jenis mikroba starter dan lama waktu fermentasi mempengaruhi jumlah asam laktat dan alkohol kefir (Usmiati dan Abubakar, 2009). Belum ada standar baku dalam pembuatan susu kefir dan belum ada standar SNI untuk susu kefir.

Zakaria (2009) menyatakan bahwa kefir memiliki manfaat untuk kesehatan pencernaan karena mampu membunuh bakteri patogen yang mengganggu pada saluran cerna. Ditambahkan oleh Yusriyah (2014) bahwa kemampuan kefir dalam menekan pertumbuhan bakteri patogen pada saluran pencernaan dikarenakan bakteri asam laktat pada kefir dapat menghasilkan senyawa antimikroba diantaranya bakteriosin, antibiotik dan hidrogen peroksida. Hong et al. (2009) melakukan penelitian terhadap kefir susu sapi perah menyatakan bahwa, salah satu komponen non mikroba kefir peptida bioaktif yang menunjukkan karakteristik imunomodulator. Peptida bioaktif ini merupakan metabolit pada kefir, sebagai hasil degradasi protein susu, selama proses fermentasi. Sehubungan dengan hal ini, LeBlanc et al. (2002) menyatakan bahwa, salah satu senyawa peptida bioaktif pada kefir, yang bersifat menginduksi respons imun bila berinteraksi dengan sel epitel dan sel-sel imun pada saluran pencernaan, selain itu kefir juga mengandung asam amino triptopan.

Kegiatan ini memfokuskan untuk melatih kemampuan peternak dalam membuat susu fermentasi kefir serta memberikan pelatihan pemasaran secara online seperti menggunakan situs - situs jual beli online dan menggunakan akun - akun media sosial yang sedang banyak digunakan masyarakat. Dengan demikian tujuan akhir kegiatan ini dalam meningkatkan pendapatan peternak melalui pengolahan susu segar menjadi kefir dapat tercapai. Dengan adanya kegiatan ini susu yang dihasilkan dapat terjual dengan harga yang lebih tinggi dan tepat sasaran mengingat sebelumnya sebagian susu dijual kepada peternak kambing perah sebagai susu pengganti anak kambing. 


\section{METODE}

Metode yang digunakan dalam mengatasi masalah peternak sapi perah di Kota Payakumbuh untuk meningkatkan penghasilan dan memperpanjang daya simpan susu yaitu melalui pemberdayaan masyarakat yang dilakukan oleh tim pengabdi melalui beberapa tahapan diantaranya:

\section{Pembelajaran dan Pendampingan (Penyuluhan)}

Pelaksanaan pembelajaran ini mengakses semua potensi kemampuan masyarakat. Proses pembelajaran dilaksanakan secara demokratis melalui metode pendidikan orang dewasa, dimana tim pengabdi hanya sebagai fasilitator dalam penyelesaian masalah. Peternak diberi materi mengenai produk olahan susu salah satunya kefir. Materi lain yang juga diberikan adalah mengenai pemasaran produk. Sedangkan pendampingan difokuskan mulai dari penyediaan bahan baku, perencanaan, pengolahan, sampai pada proses pembuatan kefir susu sapi. Tim pengabdi menyediakan peralatan dan bahan seperti granula kefir, penyaring kefir, wadah kaca untuk fermentasi serta tempat penyimpanan kefir. Melalui penyuluhan ini peternak sudah memiliki gambaran teknis pelaksanaan kegiatan. Penyuluhan ini mengantarkan peternak untuk memahami sehingga memudahkan pelaksanaan demonstrasi.

\section{Demonstrasi (Pelatihan Pembuatan Kefir)}

Metode ini memfokuskan kepada proses pembuatan kefir susu sapi. Pada metode demonstrasi dilibatkan peternak untuk melihat dan melakukan langsung pembuatan kefir susu sapi. Ini merupakan lanjutan dari materi penyuluhan karena perlu dilakukan praktek langsung untuk melatih kemampuan peternak dalam pembuatan kefir. Kefir dibuat dengan teknik modifikasi Syafitri dan Swarastuti, (2011). Pada peternak mitra 2 pelatihan diikuti oleh beberapa anggota kelompok tani sedangkan pada mitra 1 pelatihan juga diikuti oleh karyawan yang bekerja dan juga manajer kandang serta pemilik usaha peternakan sapi perah tersebut. Partisipasi dari kedua mitra sangat bagus sehingga memperlancar kegiatan ini serta lebih banyaknya masyarakat yang mengenal produk olahan susu yang berfungsi sebagai probiotik. 


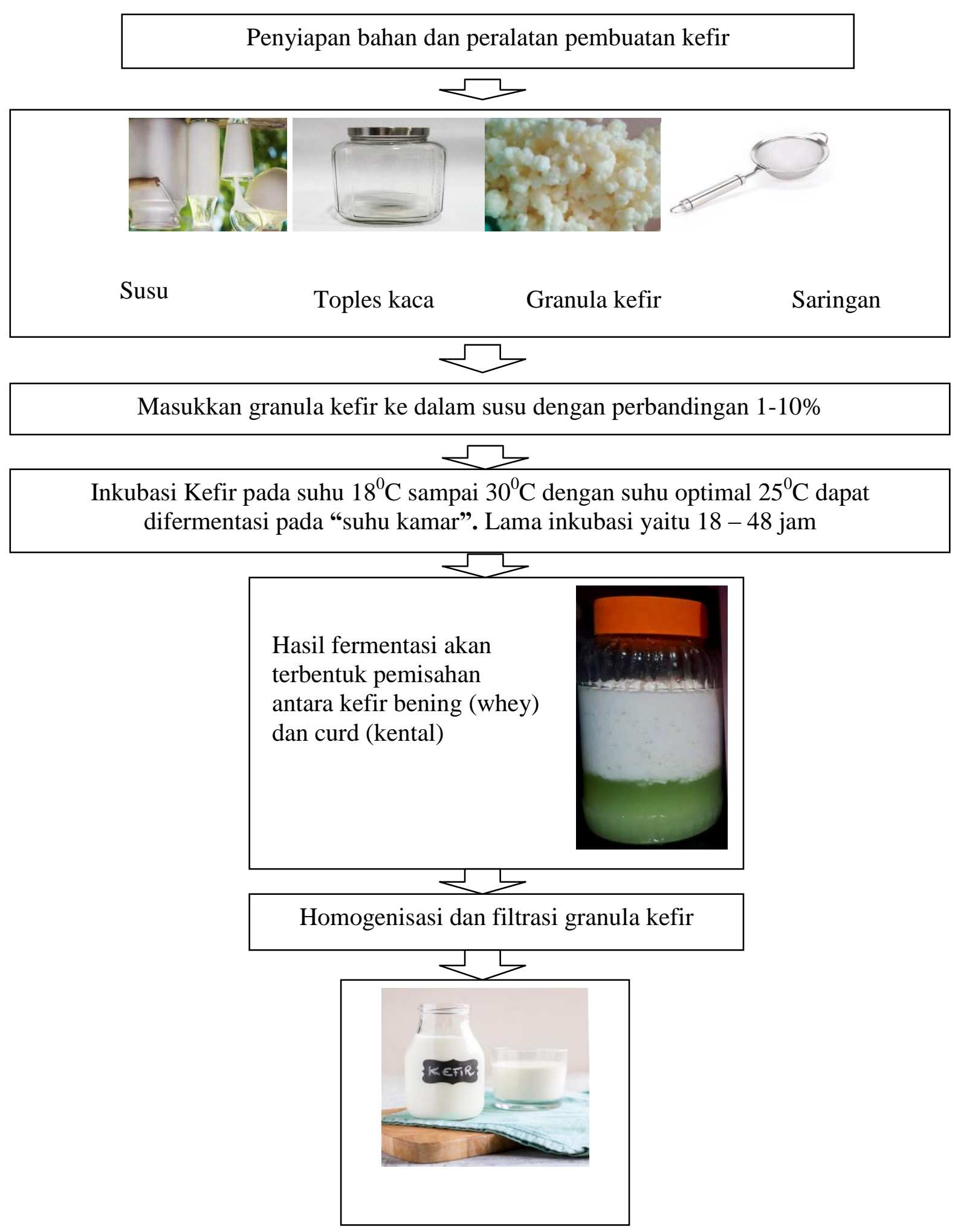

Gambar 1. Skema Proses Pembuatan Kefir 
Pelatihan dilakukan untuk memberikan keterampilan kepada peternak mengenai teknologi dalam pembuatan kefir. Dengan adanya pelatihan ini peternak selanjutnya dapat membuat sendiri dengan kreasi mereka baik diberikan perasa atau buah. Prinsip dasar pembuatan kefir diajarkan melalui pelatihan ini. Pelatihan diberikan kepada semua orang yang terlibat dalam peternakan tersebut.

\section{Strategi Pemasaran}

Menurut Suresti et al., (2018) perluasan pasar perlu dilakukan dalam meningkatkan penjualan dengan cara mengiklankan produk melalui media massa sebagai contoh iklan pada koran. Dalam hal ini Tim pengabdi memfokuskan perluasan pasar secara online di media massa seperti media jual beli online dan akun - akun yang sedang banyak digunakan masyarakat saat ini.

\section{HASIL DAN PEMBAHASAN}

Pelaksanaan kegiatan ini telah menghasilkan inovasi produk susu fermentasi berupa kefir. Menurut Muharrom et al., (2014) kefir merupakan hasil olahan susu fermentasi yang pembuatannya menggunakan granula kefir (Lactobacillus kefiri) yaitu matriks dari fermentasi yeast laktosa (Kluyveromyces marxianus) dan fermentasi yeast non laktosa (Saccharomyces unisporus, Saccharomuces cerevisae dan Saccharomyces exiguus). Pembuatan kefir pada kegiatan ini mendapat sambuatan hangat dari konsumen dan memberikan keuntungan bagi peternak. Kefir memiliki banyak khasiat karena kandungan asam amino esensial serta memiliki aktifitas antioksidan. Menurut Liu et al., (2005) aktivitas antioksidan kefir susu sapi mencapai 88,57 \%. Kefir juga dapat berperan sebagai antimikroba karena sifatnya sebagai probiotik yang dihasilkan bakteri asam laktat yang bersimbiosis dengan yeast. Menurut Febrisiantosa et al., (2013) bahwa whey kefir sangat berpotensi sebagai sumber peptida bioaktif sebagai anti hipertensi. Kefir memiliki manfaat yang sangat banyak dalam kesehatan diantaranya dapat menghambat sel tumor, menghindari terkena resiko kanker kolon, menurunkan kadar kolesterol dan mencegah terjadinya infeksi pada saluran urine (Winarno dan Fernandez., 2007).

Kefir memiliki rasa yang unik dengan rasa asam sedikit manis serta sensasi gas atau soda ditenggorokan sehingga menjadi minuman yang menyegarkan. Hal ini lah yang selanjutnya menjadi nilai jual tinggi bagi peternak. Kegiatan ini dilaksanakan dengan metode penyuluhan yaitu pembelajaran/pendidikan orang dewasa. Adapun foto kegiatan dapat dilihat pada gambar berikut: 


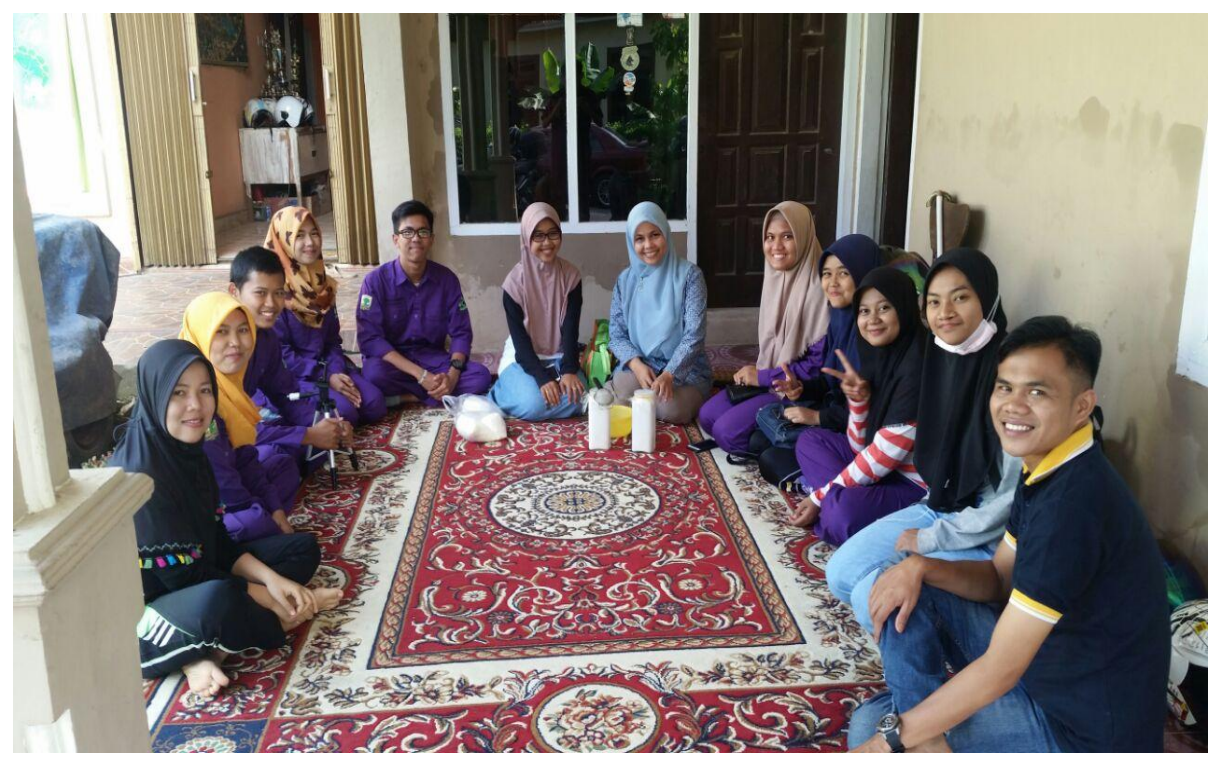

Gambar 2. Penyuluhan di Lokasi Mitra

Penyuluhan dilaksanakan untuk memberikan pengetahuan awal kepada peternak terkait dengan kefir sebagai produk olahan susu. Melalui penyuluhan ini dijelaskan titik kritis pengolahan kefir, tata cara penyimpanan granula kefir, budidaya granula kefir untuk dijual kembali serta sasaran pemasaran kefir. Granula kefir dapat bertambah jumlahnya jika dilakukan pemeliharaan dengan baik dan diberikan nutrisi yang cukup dari susu segar. Presentasi dan diskusi dengan peternak untuk mengupas berbagai keunggulan dan kelemahan dari berbagai produk-produk susu fermentasi lainnya. Penyuluhan juga dilakukan dengan melibatkan masyarakat sekitar yang diharapkan nantinya akan menjadi konsumen produk yang akan dibuat. Penyuluhan dilakukan kepada peternak dalam rangka memperbarui ilmu peternak dalam pengolahan produk peternakan. Disamping itu diharapkan timbulnya kesadaran peternak akan pentingnya teknologi dalam pengolahan susu sapi yang mampu meningkatkan pendapatan peternak. Pelaksanaan penyuluhan juga dapat dijadikan sebagai sarana promosi oleh peternak mitra dalam meningkatkan pemasaran produk-produk olahan susu.

Pelaksanaan kegiatan berlangsung sesuai dengan tahapan awal yang direncanakan. Diantaranya mulai dari penyuluhan atau pembelajaran dari pemateri. Pada tahapan ini sudah terlihat keinginan peternak sangat besar untuk melanjutkan pada tahapan demonstrasi atau pelatihan pembuatan kefir. Melalui pelatihan langsung ini peternak lebih memahami setiap tahapan pembuatan kefir. Jika mendengarkan materi pada tahapan pembelajaran saja terlihat mudah pembuatan kefir ini. Pada aplikasinya kefir tersebut sangat sensitif dengan kebersihan dan peralatan yang bersifar korosif. Perlu ketelitian dan hati-hati untuk memperoleh hasil maksimal. Dalam pelaksanaan ini peternak beberapa kali mengalami kegagalan sehingga tidak terjadi fermentasi secara sempurna. Setelah pembinaan melalui diskusi serta pengalaman menjadikan peternak lebih mahir serta pada saat ini produk sudah mulai dipasarkan

Tim pengabdi telah melakukan evaluasi terhadap hasil kegiatan ini. Evaluasi dilakukan untuk mengetahui pengetahuan peternak tentang teknologi pengolahan produk hasil ternak yang diterapkan. Dengan dilakukan evaluasi dapat dilihat sejauh mana daya serap peternak akan ilmu yang diberikan. Tindakan selanjutnya yang akan 
dilakukan adalah pembinaan. Evaluasi dilaksanakan 20 hari setelah demontrasi pembuatan kefir. Evaluasi ini berupa penerimaan jika ada keluahan - keluhan atau bahasan penting dari peternak mitra atas apa yang dilaksanakannnya. Setelah dilaksanakannya demonstrasi sebelumnya dan peternak sudah mencoba memasarkan produk kefir. Konsumen yang saat ini sangat tertarik membeli kefir adalah binaragawan serta anak - anak muda yang sedang melakukan pembesaran otot untuk mendapatkan bentuk tubuh yang ideal. Pembinaan akan dilakukan secara berkala baik diskusi secara langsung maupun via telepon.

Produk kefir yang dihasilkan sangat diterima oleh kedua mitra ternak. Pada peternakan Abe Farm Sari Bulan kefir tidak hanya dipasarkan sebagai penambah penghasilan namun juga dijadikan konsumsi bagi karyawan sebagai bentuk loyalitas perusahaan terhadap pekerja. Melalui diskusi dengan karyawan yang bekerja di peternakan tersebut tim pengabdi memperoleh informasi bahwa dengan mengkonsumsi kefir mereka menjadi tidak mudah lelah dalam bekerja. Peternak juga telah memperluas pengetahuan mengenai produk olahan kefir ini seperti sabun kefir, cream kefir, masker kefir dan pengolahan pakan serta pupuk organik kefir. Peternak mengharapkan pelatihan berikutnya dalam pengembangan usaha ini. Hasil yang diperoleh tim pengabdi melebihi dari harapan yaitu peternak lebih antusias mencari informasi terkait materi kegiatan yang diberikan.

\section{KESIMPULAN DAN SARAN}

Berdasarkan kegiatan yang telah dilaksanakan dapat disimpulkan bahwa permasalahan yang dihadapi oleh peternak sapi perah dikota Payakumbuh dapat diatasi melalui kegiatan pembuatan kefir yaitu teknologi fermentasi susu yang mengguanakan granula kefir, melalui kegiatan yang diberikan berupa pembelajaran dan pendampingan, jasa penyuluhan (melalui demonstrasi pembuatan produk). Ditinjau dari pelaksanaan kegiatan yang telah terlaksana kegiatan ini telah tepat sasaran sesuai dengan perencanaan awal. Hal ini dapat dilihat dari antusias peternak dalam menerima teknologi baru yang ditawarkan dan tidak membutuhkan waktu dalam penerapannya dan langsung digunakan oleh peternak.

Saran untuk keberlanjutan usaha peternakan diharapkan juga adanya keterlibatan pemerintah daerah dalam memperhatikan kesejahteraan peternak. Peternak sangat membutuhkan dukungan berupa moral maupun material untuk merubah pola peternakan dari yang mulanya hanya menghasilkan produk susu segar menjadi produk siap konsumsi atau siap pakai seperti es krim kefir, sabun susu, puding susu probiotik, stik susu dan lain sebagainya.

\section{UCAPAN TERIMAKASIH}

Terimakasih diaturkan kepada LPPM Univeritas Andalas yang telah mendanai kegiatan ini melalui Dana BOPTN Universitas Andalas Tahun Anggaran 2017. Sehingga dapat terlaksananya kegiatan ini dengan mitra Peternakan Sapi Perah Mandiri Abe Farm Sari Bulan dan kelompok tani ternak Tapian Agam yang berlokasi di kota Payakumbuh. Terimakasih kami ucapkan juga kepada kedua mitra yang telah 
bekerja sama sehingga tercapainya tujuan yang diharapkan.

\section{DAFTAR PUSTAKA}

Febrisiantosa A., Bagus P. P., Irma I. A dan Yantyati W. 2013. Karakteristik fisik, kimia dan mikrobiologi whey kefir dan aktivitasnya terhadap penghambatan angiotensin converting enzyme (ACE). Jurnal Teknologi dan Industri Pangan. 24(2): 147-153.

Hong, W-S., H.C. Chen, Y.Chen and M.J. Chen. 2009. Effects of kefir supernatant and lactic acid bacteria isolated from kefir grain on in vitro cytokine production through a toll-like receotor pathway. International Dairy Journal. 19: 244-251.

LeBlanc, J.G., C. Matar, J.C. Valdez, J. LeBlanc and G. Perdigón. 2002. Immunomodulating eff ects of peptidic fractions issued from milk fermented with Lactobacillus helveticus. J. Dairy Sci. 85(11): 2733-2742.

Liu R. J., Yuh Y. L., Ming J. C., Li J. C and Chin W. L. 2005. Antioxidative activities of kefir. Asian-Aust. J. Anim. Sci. 18(4) : 567-573.

Muharrom, D.K., Purwadi. L.E. Radiati. 2014. Pengaruh Kombinasi Thickening Agent Carboxymethylcelluluose (CMC) dan Gel Lidah Buaya (Aloe Barbandensis Miller) Terhadap Sifat Fisik Dan Total Bakteri Asam Laktat (BAL) Es Krim Kefir. Repository Fakultas Peternakan. Universitas Brawijaya, Malang.

Usmiati, S., Abubakar. 2009. Teknologi Pengolahan Susu. Balai Besar Penelitian dan Pengembangan Pascapanen Pertanian, Bogor.

Suresti A., Salam N. A., Rahmi W. 2018. Pengembangan usaha kelompok produsen dadih di Kecamatan Tilatang Kamang. Jurnal Hilirisasi IPTEKS. 1(3): 33-42.

Winarno, F.G. dan I. E. Fernandez 2007. Susu dan Produk Fermentasinya. M-brio Press, Bogor.

Zakaria Y. 2009. Pengaruh jenis susu dan persentase starter yang berbeda terhadap kualitas kefir. Agripet. 9(1): 26-30. 